\title{
Hubungan Pola Asuh Dengan Karakter Berwirausaha Pada Lulusan Perguruan Tinggi Di Indonesia
}

\author{
Nurul Fadhilah Khair, Risanita Fardian Farid, Welan Mauli Angguna \\ Fakultas Psikologi , UPI YPTK, Padang, Indonesia \\ Email: nurulfadhilahkhair@ upiyptk.ac.id, risanita.fardian@upiyptk.ac.id, welanmauli@upiyptk.ac.id
}

\begin{abstract}
Relationship of Parenting Patterns With Entrepreneured Characters Graduations In Indonesia. There has been an increase in the number of educated unemployed who come from college graduates (diploma \& bachelor degree), making the government encourage graduates to become entrepreneurs with various facilities and policies. However, not everyone has the will and ability to be entrepreneurial. The creation of entrepreneurship is not only influenced by environmental support, personal characteristics today are considered a significant variable influencing the creation of entrepreneurship. It is known that positive parenting that provides proper autonomy to children is related to the independent, courageous, and creative character that characterizes entrepreneurship. This study aims to determine whether the (authoritative) parenting style is positively related to the entrepreneurial character of Indonesian university graduates. This study is a non-experimental correlational quantitative survey method using entrepreneurial character measurement using the Entrepreneurial Scale (SK-WIRA) and Parenting Patterns using the Parenting Authoritative Questionnaire (PAQ). It was found that there was no significant negative relationship between authoritarian parenting and the entrepreneurial character of college graduates ( $p>0.05)$. The null hypothesis is accepted and the alternative hypothesis is rejected.
\end{abstract}

Keywords: Entrepreneurial character, parenting, college graduate

\begin{abstract}
Abstrak
Hubungan Pola Asuh dengan Karakter Berwirausaha pada Lulusan Perguruan Tinggi di Indonesia. Terjadi peningkatan jumlah pengangguran terdidik yang berasal dari lulusan perguruan tinggi (diploma \& sarrjana) membuat pemerintah menggenjot para lulusan untuk berwirausaha dengan berbagai fasilitas dan kebijakan. Namun demikian, tidak semua orang memiliki kemauan dan kemampuan untuk beriwirausaha. Terciptanya wirausaha tidak hanya dipengaruhi oleh dukungan lingkungan saja, karakteristik pribadi dewasa ini dianggap sebagai variabel yang cukup signifikan memengaruhi terciptanya wirausaha. Diketahui bahwa polaasuh positif yang memberikan otonomi secara tepat pada anak berhubungan dengan karakter yang mandiri, berani, dan kreatif yang menjadi karakteristik wirausaha. Penelitian ini bertujuan untuk mengetahui apakah pola asuh (otoritatif) berhubungan positif dengan karakter wirausaha pada lulusan perguruan tinggi Indonesia. Studi ini adalah kuantitatif correlational non-eksperimental menggunakan metode survei pengukuran karakter wirausaha menggunakan Skala Wirausaha (SK-WIRA) dan Pola Asuh menggunakan Parenting Authoritative Questionnaire $(P A Q)$. Ditemukan bahwa tidak terdapat hubungan negative yang signifikan antara pola asuh otoriter dengan karakter wirausaha lulusan perguruan tinggi $(\mathrm{p}>0,05)$, hipotesis null diterima dan hipotesis alternatif ditolak.
\end{abstract}

Kata kunci : karakter wirausaha ; pola asuh ; lulusan perguruan tinggi

\section{Pendahuluan}

Berdasarkan rilis data Badan Pusat Statistik menunjukkan adanya peningkatan jumlah pengangguran hingga 6,88 juta orang per Februari 2020. Semenjak terjadinya wabah covid-19 menambah jumlah pengangguran yang didominasi oleh kelompok usia produktif (15-24 tahun) sebanyak $16,28 \%$, selain itu semakin banyak juga lulusan diploma dan sarjana yang menganggur di tahun 2020 [1] Meningkatnya jumlah pengangguran pada lulusan perguruan tinggi yang semakin marak semenjak pandemi covid 19 dan ketidak-pastian ekonomi global, menuntut para lulusan untuk berwirausaha. Rully Indrawan, Sekretaris Kementrian Koperasi dan UKM menyarankan lulusan sarjana untuk menjadi job creator dan bukan job seeker. KEMKOP dan UKM berharap para milenial dengan dayakreatif secara inovatif berkarya melalui usaha kreatif. Pemerintah menyiapkan 6 program strategis untuk pengembangan UMKM, antara lain: perluasan akses pasar, peningkatan daya saing, pengembangan kewirausahaan, akselerasi pembiayaan, kemudahan dan kesempatan usaha, dan koordinasi lintas sector dengan menggandeng berbagai

Diterima Redaksi : 11-12-2020 | Selesai Revisi : 28-04-2021 | Diterbitkan Online : 01-05-2021 
pihak untuk pengembangan UMKM [2] Pengangguran dengan tingkat pendidikan yang tinggi mendominasi dalam jumlah pengangguran di Sumatera Barat. Tingginya tingkat pendidikan dari calon tenaga kerja, tidak berbanding lurus dengan lapangan pekerjaan yang tersedia [3]. Banyak dari pengangguran terdidik yang berharap mendapatkan pekerjaan sesuai dengan jenjang pendidikan mereka, selain itu ekspektasi yang tinggi terhadap salary membuat mereka cenderung memilih pekerjaan tanpa memiliki pengalaman yang cukup sebelumnya. Hal ini dikuatkan dengan data wawancara yang peneliti lakukan pada Agustus 2019 terhadap tiga orang calon tenaga kerja di kota Padang. Ketiga calon tenaga kerja menyatakan bahwa mereka menginginkan pekerjaan yang bagus dengan range gaji yang tinggi sehingga lebih sering menolak jika mendapatkan tawaran pekerjaan yang tidak sesuai dengan ekspektasi. Jumlah pengangguran sebenarnya dapat ditekan, jika setiap pencari kerja mampu masuk dalam industri ekonomi kreatif. Industri ekonomi kreatif berbasis kreatifitas yang dapat meningkatkan pertumbuhan ekonomi di suatu daerah. Ekonomi kreatif merupakan paradigma ekonomi gelombang ke 4, yang berdasarkan pada kreativitas, budaya, warisan budaya dan lingkungan [4]. Perkembangan industri ekonomi kreatif di Indonesia berjalan cukup baik, namun belum sesuai harapan karena terdapat beberapa faktor penghambat perkembangan. Diantaranya adalah, peningkatan kuantitas dan kualitas sumber daya manusia yang kreatif, sehingga dapat menciptakan lapangan pekerjaannya sendiri, disebut juga sebagai karakter wirausaha [5]. Berdasarkan hal tersebut disimpulkan bahwa, kreativitas merupakan modal utama bagi para pencari kerja agar mampu masuk dalam industri ekonomi kreatif di Indonesia sehingga tidak lagi menganggur. Aktivitas wirausaha terjadi ketika terdapat kombinasi antara lingkungan yang memberikan kesempatan usaha dan pribadi individu yang mau berusaha [6]. Namun demikian, tidak semua orang memiliki kemauan dan mampu berkecimpung di bidang ini, hal ini menunjukkan bahwa untuk berwirausaha diperlukan kriteria pribadi yang memengaruhi intensi untuk berwirausaha yang dikenal sebagai karakter berwirausaha. Karakter wirausaha merujuk pada semangat, sikap kreatif, serta keberanian dalam mengambil resiko yang telah diperhitungkan berdasarkan kemauan serta kemampuan sendiri [5]. Kewirausahaan adalah semangat, perilaku dan kemampuan untuk memberikan tanggapan positif terhadap peluang usaha, guna memperoleh keuntungan untuk diri sendiri atau lingkungan sekitar dengan selalu berusaha, menciptakan, menyediakan produk, menerapkan cara kerja efisien, melalui keberanian mengambil resiko, kreativitas dan inovasi serta kemampuan manajemen [7]. Dapat diketahui bahwa karakter wirausaha merupakan individu dengan semangat, sikap kreatif, keberanian dan memiliki kemampuan manajemen yang unik. Karakter kewirausahaan bisa ditumbuhkan dalam keluarga. Istilahkeluarga pada Undang Undang Dasar Negara Republik Indonesia tertulis pada UU Nomor 10 Tahun 1992 Pasal 1 Ayat 10 yang diartikan sebagai unit terkecil dalam masyarakat yang terdiri dari hubungan suami-isteri, atau suami-isteri dan anaknya atau ayah dan anaknya atau ibu dan anaknya [8]. Orangtua memegang peranan penting dalam keluarga, dimana peranan kedua orangtua dalam pola pengasuhan sangat dibutuhkan oleh perkembangan anak. Berdasarkan penelitian yang dilakukan terdahulu menyebutkan bahwa rendahnya keterlibatan salah satu atau kedua orangtua pada pola pengasuhan berdampak pada buruknya attachment antara orangtua dan anak [9] [10]. Keluarga dengan attachment yang buruk akan memunculkan berbagai permasalahan emosional pada setiap anggotanya [11]. Hal ini disebabkan karena secara emosional setiap anggota keluarga saling terkait antara satu dengan yang lain [12] sehingga remaja dengan permasalahan tertentu akan mudah bangkit dari permasalahan tersebut jika mendapat dukungan emosional penuh dari keluarga [13] [14]. Keluarga dengan sistem yang baik serta hangat akan menurunkan resiko gangguan psikologis pada setiap anggotanya [15]. Oleh karena itu diketahui bahwa pola asuh dalam keluarga berkontribusi untuk mengembangkan karakter wirausaha pada individu calon tenaga kerja.

Pola asuh yang otoritatif ditunjukkan melalui respon yang hangat, penuh dukungan, dan kasih sayang secara konsisten berkaitan dengan hasil-hasil perkembangan yang positif secure attachment, hubungan baik dengan teman sebaya, self esteem yang tinggi, kepemimpinan, penyesuaian diri yang baik, optimism, harapan dan kebahagiaan yang tinggi [16]. Pola asuh otoritatif juga memiliki efek positif pada lima karakter utama untuk berwirausaha [17] di antaranya: kemurnian (authenticity), kepemimpinan, keadilan, rasa syukur dan semangat [16]. Karakter kewirausahaan tersebut menurut Soetjiningsih perlu diterapkan sejak usia dini, orangtua 
memegang peranan penting dalam pembentukannya, dengan demikian orangtua perlu menerapkan pola asuh otoritatif yang mendukung perkembangan karakter wirausaha [16].

Pola asuh otoritatif yang mengembangkan kebebasan pada anak di bawah supervisi orangtua, mampu meningkatkan karakter positif seperti: kemandirian, percaya diri, visioner dan orientasi masa depan [18]. Karakter wirausaha adalah sifat kepribadian yang menunjukkan kapasitas individu untuk berwirausaha. Karakter tersebut yang terdiri atas; motivasi berprestasi, inovatif, pengambilan risiko dan otonomi [6].

Lulusan perguruan tinggi dewasa ini diharapkan untuk menjadi pembuka lapangan kerja, bukan lagi sebagai pencari kerja. Terbentuknya wirausaha adalah kombinasi dukungan lingkungan dan pribadi yang mau berwirausaha. Pemerintah dewasa ini mendorong lulusan untuk berwirausaha dengan berbagai kemudhan, namun tidak semua orang mau dan mampu berwirausaha, dibutuhkan karakteristik pribadi yang berani, mandiri dan kreatif untuk mewujudkan hal tersebut. Karakter wirausaha yang demikian dikembangkan dari pola asuh yang mengembangkan kemandirian, kreativitas dan keberanian mengambil risiko dengan memberikan anak otonomi yang terarah. Oleh sebab itu penelitian ini ingin menguji apakah otoritas yang diberikan orangtua kepada anak (otonomi) berhubungan dengan karakter berwirausaha pada lulusan perguruan tinggi di Indonesia.

\section{Metode Penelitian}

\subsection{Desain Penelitian}

Penelitian ini adalah studi kuantitiatif non-experimental cross-sectional study design dengan tujuan menguji hubungan pola asuh (otoritatif) dengan karakter wirausaha pada lulusan perguruan tinggi di Indonesia. Pengambilan data dilakukan dalam satu kali dengan populasi lulusan perguruan tinggi di Indonesia yang telah lulus selama minimal 1 tahun (minimal sejak 2019). Pengukuran variabel dilakukan dengan alat ukur self-report secara daring melalui google form pada target sampel sebesar 100 responden yang memenuhi kriteria. Menurut Cohen, semakin besar ukuran sampel semakin baik [19], dan ukuran sampel yg baik untuk 6 prediktor adalah 100 responden.

\subsection{Prosedur Penelitian}

a. Reviu Artikel jurnal dan penulisan proposal penelitian.

b. Melakukan proses adaptasi dan uji validitas alat ukur: parenting authority questionnaire dan SK-WIRA

c. Mengambil data penelitian dengan menyebarkan kuesioner online melalui berbagai media sosial, seperti: whatsapp, Instagram, facebook, dll

d. Mengolah data peneltian

\subsection{Populasi dan Sampel Penelitian}

Populasi penelitian adalah dengan kriteria berikut:

a. Lulusan perguruan tinggi negeri maupun swasta di Indonesia

b. Sudah diwisuda selama minimal 1 tahun (minimal sejak 2019)

c. Belum bekerja atau saat ini sudah berhenti bekerja dan sedang mencari pekerjaan baru dan tidak sedang menjalankan usaha atau bisnis sendiri.

\subsection{Teknik Sampling}

Studi ini menggunakan Teknik accidental non-random sampling yang mengakses sampel yang sesuai dan tersedia untuk menjadi responden penelitian.

\subsection{Instrumen Penelitian}

Instrument yang digunakan di dalam penelitian ini, diantaranya adalah:

a. Skala karakter wirausaha: SK-WIRA yang dikembangkan oleh [6] menguji karakteristik wirausaha dalam 4 dimensi: keinovatifan, otonomi, motivasi berprestasi, dan pengambilan risiko yang terdiri atas 22 aitem favorabel. Skala ini memiliki validitas cukup baik (>0.3) dan 
reliabilitas yang baik $(>0,7)$.

b. Skala pola asuh: Parenting Authority Questionnaire yang terdiri atas 10 aitem dikembangkan oleh [20]. Alat ukur Parental Authority Questionnaire (PAQ) merupakan alat ukur berbentuk self-report yang didesain untuk mengukur perspektif anak terhadap pola asuh otoriter yang dilakukan oleh orang tua mereka. Alat ukur ini memiliki nilai validitas yang cukup baik $(>0,3)$ dan reliabilitas yang baik $(>0,8)$.

\section{Hasil Dan Pembahasan}

\subsection{Hasil}

a. Gambaran Partisipan

Tabel 1. Status Kerja

\begin{tabular}{llrrrr}
\hline \multicolumn{7}{c}{ Status kerja } & & \\
\hline \multirow{5}{*}{ Valid } & \multicolumn{7}{c}{ Frequency } & Percent & Valid Percent & Cumulative Percent \\
\cline { 2 - 6 } & BB & 26 & 38.2 & 38.2 & 38.2 \\
\cline { 2 - 6 } & FL & 7 & 10.3 & 10.3 & 48.5 \\
\cline { 2 - 6 } & FT & 25 & 36.8 & 36.8 & 85.3 \\
\cline { 2 - 6 } & R & 10 & 14.7 & 14.7 & 100.0 \\
\cline { 2 - 6 } & Total & 68 & 100.0 & 100.0 & \\
\hline
\end{tabular}

Partisipan dalam penelitian ini berjumlah 68 orang dengan rincian 38,2\% (26 orang) belum bekerja; 10,3\% (7 orang) bekerja sebagai freelancer; $36,8 \%$ (25 orang) merupakan pekerja full time; dan 14,7\% (10 orang) baru saja resign dari pekerjaan sebelumnya. Berdasarkan tingkat pendidikannya, kategori partisipan diantaranya:

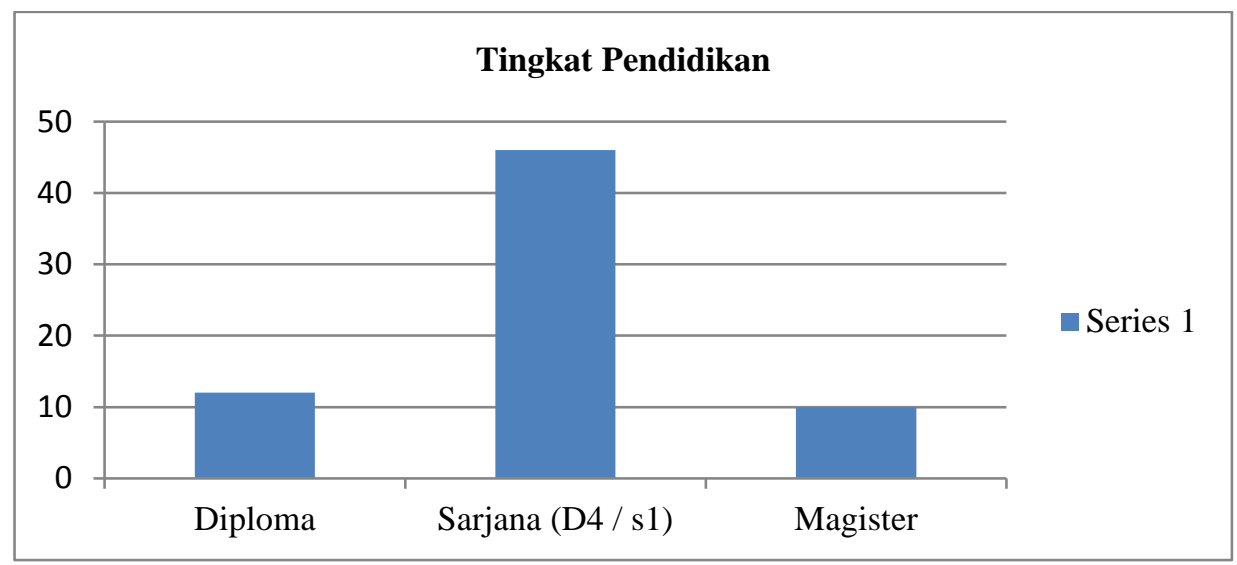

Gambar 1. Tingkat Pendidikan Partisipan

Tingkat pendidikan tertinggi partisipan penelitian, adalah Magister (S2) sebanyak 10 orang $(14,70 \%)$, Sarjana sebanyak 46 orang $(67,64 \%)$ dan Diploma sebanyak 12 orang $(17,64 \%) .49$ orang diantaranya pernah menjalani perkuliahan kewirausahaan, dan 19 orang lainnya tidak pernah mendapatkan mata kuliah kewirausahaan. Dari keseluruhan partisipan, terdapat 3 orang yang menyelesaikan masa studi 2 kali lipat lebih lama dibandingkan partisipan lainnya. Mereka menempuh pendidikan sarjana dan masing-masing menyelesaikan studi dalam waktu 10, 11 dan 13 semester.

Tabel 2. Status Wirausaha

\begin{tabular}{l|l|r|r|r|r}
\hline \multicolumn{2}{c|}{} & \multicolumn{2}{c}{ Status Wirausaha } & \multicolumn{2}{c}{$\begin{array}{c}\text { Cumulative } \\
\text { Percent }\end{array}$} \\
\hline \multirow{2}{*}{ Valid } & 1 & Frequency & Percent & Valid Percent & 41.2 \\
\cline { 2 - 6 } & 2 & 28 & 41.2 & 41.2 & 100.0 \\
\cline { 2 - 6 } & Total & 40 & 58.8 & 58.8 & 100.0 \\
\hline
\end{tabular}


Berdasarkan data, ditemukan bahwa dari 68 orang partisipan hanya sejumlah 28 orang $(41,2 \%)$ yang memilih untuk melakukan wirausaha sedangkan 40 orang $(58,8 \%)$ diantaranya tidak melakukan wirausaha. Lama waktu berwirausaha, kemudian dibagi dalam 3 kelompok yaitu: a) menjalani wirausaha kurang lebih dibawah 3 bulan, sebanyak 12 orang; b) kelompok yang menjalani wirausaha antara 4 bulan hingga 1 tahun, sebanyak 3 orang dan; c) kelompok yang menjalani wirausaha lebih dari 1 tahun sebanyak 13 orang. Jenis wirausaha yang mereka tekuni pun bervariasi, diantaranya bidang Kuliner, Fashion, Otomotif, Jasa yang dominan dilakukan via Online (Online-Shopping).

\subsection{Gambaran Variabel}

\section{a. Karakter Wirausaha}

Variabel dependen dari penelitian ini adalah karakteristik wirausaha, yaitu keinovatifan, otonomi, motivasi berprestasi, dan pengambilan risiko. Berdasarkan hasil analisis, ditemukan bahwa terdapat perbedaan karakter wirausaha pada partisipan. Nilai signifikansi dua arah (ttailed) $0.274<0.05$, disimpulkan bahwa terdapat karakter wirausaha yang signifikan antara lulusan perguruan tinggi yang melakukan wirausaha dan yang tidak melakukan wirausaha.

Berdasarkan nilai deskriptifnya, terbukti bahwa lulusan perguruan tinggi yang melakukan wirausaha memiliki karakter wirausaha berupa keinovatifan, otonomi, motivasi berprestasi, dan pengambilan risiko dibandingkan lulus perguruan tinggi yang tidak melakukan wirausaha. Mata kuliah kewirausahaan, umumnya selalu dijadikan mata kuliah wajib yang dipelajari oleh lulusan sarjana. Dari data yang ada ditemukan bahwa terdapat kaitan antara mata kuliah kewirausahaan yang diterima saat kuliah, dengan karakter dan pilihan untuk melakukan wirausaha. Dijelaskan pada tabel berikut:

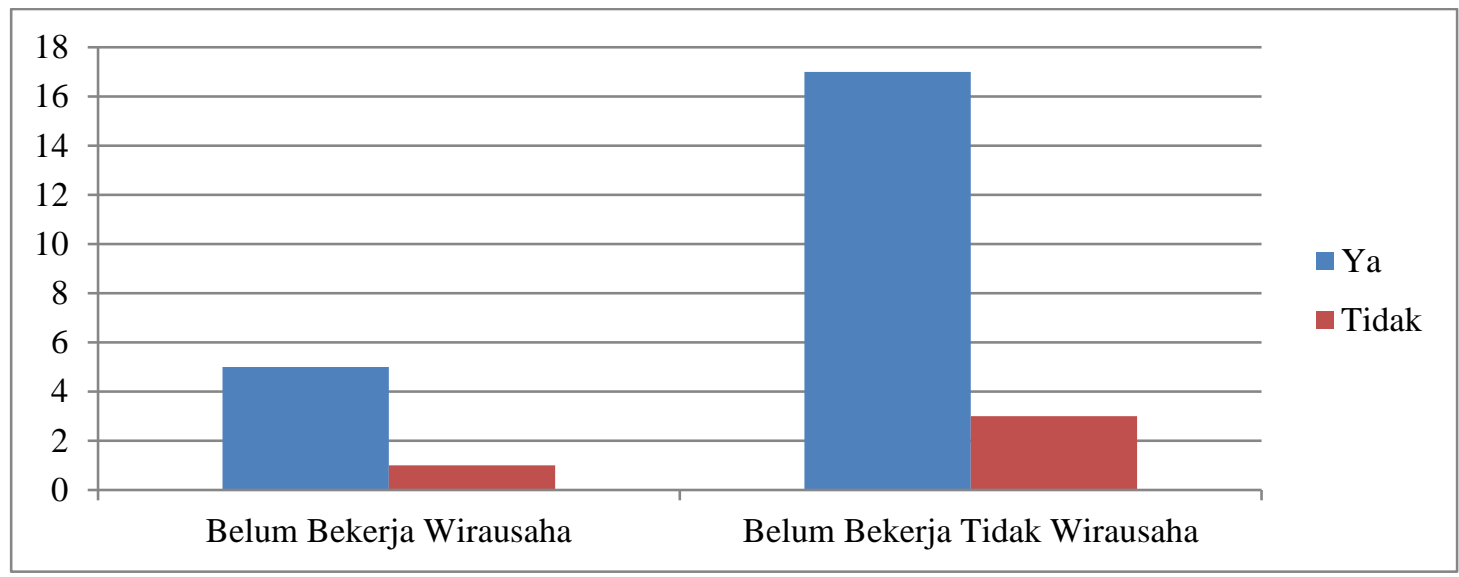

Gambar 2. Mata Kuliah Kewirausahaan partisipan belum bekerja

Terlihat bahwa dalam kategori individu yang belum bekerja sama sekali semenjak kelulusan, sejumlah 6 orang yang saat ini sedang melakukan wirausaha dimana 5 diantaranya mendapatkan mata kuliah kewirausahaan. Sebaliknya sebanyak 21 orang dari partisipan yang belum bekerja semenjak kelulusan, 17 orang diantaranya mendapatkan mata kuliah kewirausahaan. Disimpulkan bahwa pada kategori ini, lulusan sarjana dominan mempelajari matakuliah kewirausahaan dibangku perkuliahan. 


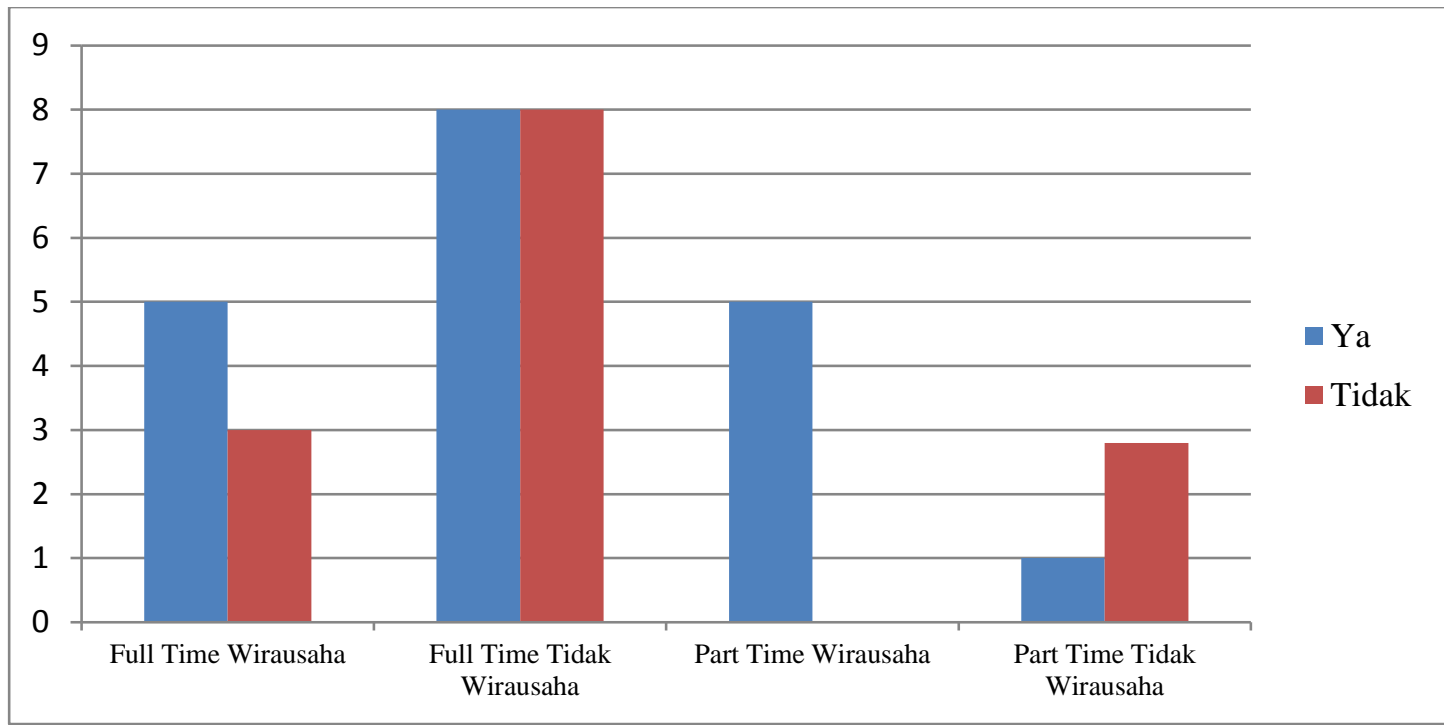

Gambar 3. Mata Kuliah Kewirausahaan partisipan bekerja

Pada keseluruhan partisipan yang saat ini sedang bekerja, mayoritas diantaranya mendapatkan mata kuliah kewirausahaan ketika kuliah. Kategori partisipan yang sedang bekerja part time, keseluruhannya mendapatkan mata kuliah kewirausahaan ketika kuliah.

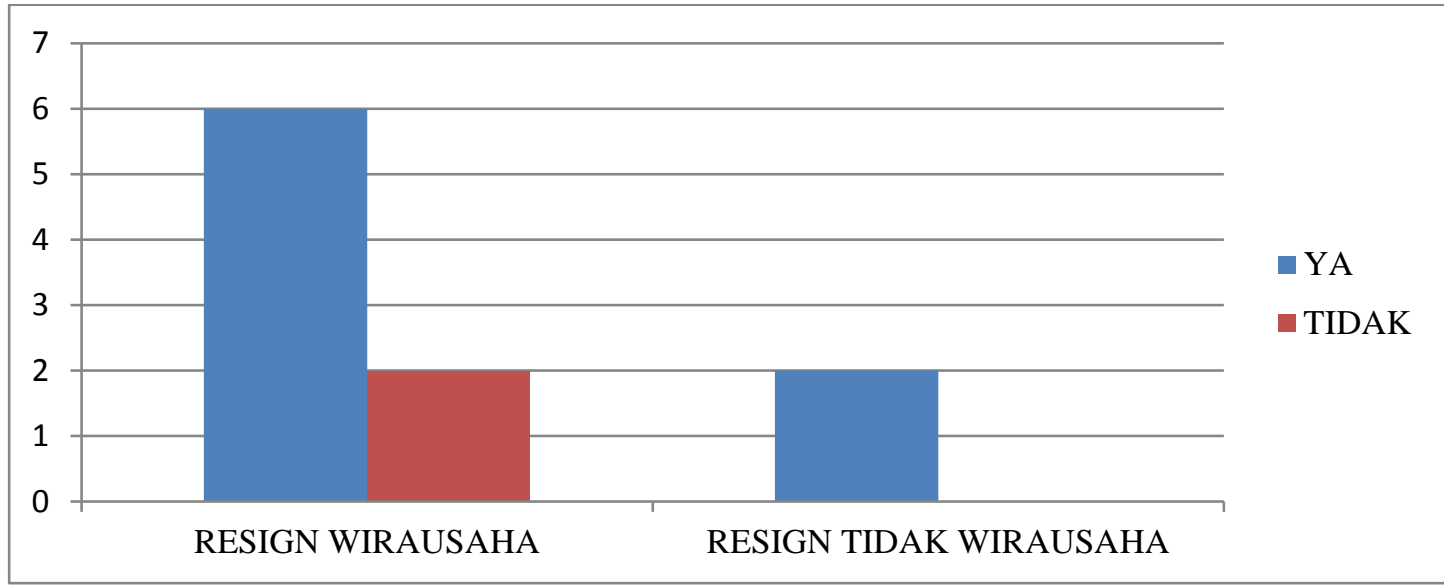

Gambar 4. Mata Kuliah Kewirausahaan partisipan resign

Partisipan yang memilih untuk berhenti dari pekerjaan sejumlah 10 orang, dimana 8 orang diantaranya memutuskan berhenti bekerja karena ingin melakukan wirausaha. Tidak berbeda dengan dua kategori sebelumnya, pada kategori ini mayoritas partisipan mendapatkan kuliah kewirausahaan dan hanya dua orang diantaranya yang tidak mendapatkan mata kuliah tersebut.

\section{b. Pola Asuh}

Alat ukur digunakan untuk melihat pengasuhan authoritative yang dilakukan oleh kedua orangtua dan persepsi anak terhadap hal tersebut. Alat ukur ini berbentuk self-item report yang berisikan persepsi setiap anak mengenai pengasuhan yang dilakukan oleh orangtuanya. Semakin tinggi skor yang dihasilkan, maka diketahui bahwa pengasuhan authoritative semakin dominan diterapkan oleh orangtua di dalam keluarga. Skala ini memiliki skor minimal 10, dan skor maksimal 50. 
Tabel 4. Parenting Authority Question

\begin{tabular}{|c|c|c|c|c|c|c|c|}
\hline \multicolumn{8}{|c|}{ Descriptive Statistics } \\
\hline & $\mathrm{N}$ & Minimum & Maximum & Mean & $\begin{array}{c}\text { Std. } \\
\text { Deviation }\end{array}$ & \multicolumn{2}{|c|}{ Skewness } \\
\hline & Statistic & Statistic & Statistic & Statistic & Statistic & Statistic & $\begin{array}{c}\text { Std. } \\
\text { Error }\end{array}$ \\
\hline polaasuh & 68 & 12 & 50 & 27.18 & 10.863 & .638 & .291 \\
\hline $\begin{array}{l}\text { Valid N } \\
\text { (listwise) }\end{array}$ & 68 & & & & & & \\
\hline
\end{tabular}

Dari 68 orang partisipan, ditemukan bahwa skor pengasuhan authoritative paling rendah adalah 12 sedangkan yang paling tinggi adalah 50. Ditemukan bahwa persepsi setiap partisipan terhadap pengasuhan kedua orangtuanya bervariasi.

c. Hubungan antara karakter wirausaha dengan pola asuh.

Asumsi awal penelitian menunjukkan bahwa adanya hubungan negative yang signifikan antara dua variable. Dimana, semakin tinggi pola asuh authoritative yang diterimanya dalam keluarga maka semakin rendah karakter wirausaha yang dimilikinya. Begitu pun sebaliknya. Berdasarkan uji asumsi dengan uji analisis korelasi pearson ditemukan bahwa:

Tabel 5. Hubungan Pola Asuh dan Kewirausahaan

\begin{tabular}{|c|c|c|c|}
\hline \multicolumn{4}{|c|}{ Correlations } \\
\hline & & polaasuh & skwira \\
\hline \multirow[t]{3}{*}{ polaasuh } & Pearson Correlation & 1 & -.062 \\
\hline & Sig. (1-tailed) & & .307 \\
\hline & $\mathrm{N}$ & 68 & 68 \\
\hline \multirow[t]{3}{*}{ skwira } & Pearson Correlation & -.062 & 1 \\
\hline & Sig. (1-tailed) & .307 & \\
\hline & $\mathrm{N}$ & 68 & 68 \\
\hline
\end{tabular}

Tidak ada hubungan yang signifikan antara pola asuh dengan karakter wirausaha. Pengasuhan yang diberikan oleh kedua orangtua dan diterima semenjak kecil oleh seseorang, tidak mempengaruhi munculnya karakter wirausaha berupa keinovatifan, otonomi, motivasi berprestasi, dan pengambilan risiko.

\section{Kesimpulan:}

Tujuan dari penelitian ini adalah untuk mengetahui adanya kaitan antara pola asuh, dengan karakter wirausaha pada lulusan perguruan tinggi di Indonesia. Sebanyak 68 orang partisipan penelitian, ditemukan bahwa sebanyak 27 orang saat ini belum bekerja atau sedang mencari pekerjaan. 31 orang diantaranya sedang bekerja, baik full time atau part time. Sedangkan 10 orang lainnya baru saja memutuskan kontrak atau berhenti dari pekerjaan. Uji korelasi menunjukkan, bahwa tidak ada hubungan negative signifikan antara pola pengasuhan dengan karakter wirausaha pada lulusan perguruan tinggi di Indonesia dengan hasil signifikansi ( $>0,05)$. Pola asuh authoritative tidak berhubungan dengan kesuksesan seorang wirausahawan [21]

Berdasarkan skor yang di dapatkan, disimpulkan bahwa terdapat partisipan yang memiliki persepsi pengasuhan authoritative yang tinggi. Seorang anak yang dibesarkan dengan pola asuh authoritative, lebih mudah dalam memilih karir karena selalu mendapatkan arahan dari kedua orangtuanya. Menurut penelitian yang dilakukan oleh Firdaus, pengasuhan authoritative oleh kedua orangtua, memberikan sumbangan efektif sebanyak $27,4 \%$ terhadap pengambilan 
keputusan karir oleh siswa SMK di kota Semarang [22].

Pengasuhan authoritative yang diberikan oleh kedua orangtua dan diterima semenjak kecil oleh seseorang, tidak mempengaruhi munculnya karakter wirausaha berupa keinovatifan, otonomi, motivasi berprestasi, dan pengambilan risiko. Hal ini disebabkan karena seorang anak yang dibesarkan dengan pengasuhan otoriter, akan tumbuh menjadi seseorang yang kurang mandiri, dan memiliki kemampuan sosial dan kognitif yang lebih rendah jika dibandingkan dengan anak-anak lainnya [23]. Karakter ini, sangat bertolak belakang dengan karakter kewirausahaan berupa otonomi dan pengambilan risiko.

Faktor lain yang mempengaruhi minat kewirausahaan adalah, perkuliahan kewirausahaan yang diterima di bangku perkuliahan. Dari ketiga kategori partisipan, mendominasi menerima kurikulum kewirausahaan dan mempelajarinya di bangku kuliah. Terdapat hubungan yang signifikan antara perkuliahan kewirausahaan, dengan intensitas berwirausaha yang dimiliki lulusan perguruan tinggi [24], teori ini di dukung dari hasil penelitian. Ditemukan bahwa dari ketiga kategori partisipan yang melakukan wirausaha, keseluruhannya menjalani perkuliahan kewirausahaan ketika duduk di bangku perkuliahan. Sejalan dengan penelitian sebelumnya yang menyatakan bahwa pendidikan kewirausahaan di bangku perkuliahan, mampu memunculkan intensi dan mempengaruhi keputusan seseorang dalam melakukan wirausaha [25].

\section{Saran}

Temuan lain dari penelitian ini menunjukkan, adanya partisipan yang sudah melakukan wirausaha lebih dari empat tahun namun ia tetap bekerja dan menerima gaji setiap bulan secara rutin dengan jumlah yang tetap. Perlu dikaji, faktor apa yang kemudian mempengaruhi pemilihan keputusan untuk tetap melakukan wirausaha dan bekerja dalam waktu yang sama kepada setiap partisipan.

\section{Daftar Rujukan}

[1] C. A. Putri, "CNBC Indonesia," Trans Media Company, 1 Juli 2021. [Online]. Available: https://www.cnbcindonesia.com. [Diakses 3 Januari 2019].

[2] Humas Kementerian Koperasi dan UKM, "Kementrian Koperasi dan UKM Republik Indonesia," Kementrian Koperasi dan UKM , 3012 2020. [Online]. Available: https://www.kemenkopukm.go.id/. [Diakses 30 Januari 2019].

[3] M. S, "Dinamika pengangguran terdidik: tantangan menuju bonus demografi di Indonesia.," J. Econ. Econ. Educ, pp. 124-136, 2015.

[4] R. A. Purnomo, Ekonomi Kreatif: Pilar Pembangunan Indonesia, Surakarta: Ziyad Visi Media, 2016.

[5] “Warta Ekonomi," 13 Agustus 2016. [Online]. Available: https://www.wartaekonomi.co.id/. [Diakses 13 Januari 2019].

[6] A. N. Husna, "Karakter Wirausaha sebagai Anteseden Efikasi Diri dan Intensi Berwirausaha pada Mahasiswa," dalam The 10th University Research Colloqium 2019 Sekolah Tinggi Ilmu Kesehatan Muhammdiyah Gombong, 2019, 2019.

[7] Sukijo, Membudayakan Kewirausahaan, Yogyakarta : Universitas Negeri Yogyakarta, 2017.

[8] "Undang-Undang Republik Indonesia Nomor 10 Tahun 1992 tentang Perkembangan Kependudukan dan Pembangunan Kependudukan dan Pembangunan Keluarga Sejahtera," Jakarta, 1992.

[9] T.-M. Bynion, H. Blumenthal dan S. A. Bilsky, "Dimensions of parenting among mothers and fathers in relation to social anxiety among female adolescents," Journal of Adolescene, pp. 11-15, 2017.

[10] E. Flouri, E. Midouhas dan M. K. Narayanan, "The Relationship Between Father Involvement and Child Problem Behaviour in Intact Families: A 7-Year Cross-Lagged Study," Journal of Abnormal Child Psychology, p. 1011-1021, 2016.

[11] H. Freeman dan B. B. Brown, "Primary Attachment to Parents and Peers During," Journal of Youth and Adolescence, vol. 30, no. 6, pp. 653-674, 2001.

[12] "ISS Family Institute," International Sosial Service Hong Kong Branch, 2019. [Online]. Available: http://www.isshk.org/. [Diakses 15 Maret 2019]. 
[13] S. Vidal, D. Prince , C. M. Connell, C. M. Caron, J. S. Kaufman dan K. J. Tebes , "Maltreatment, family environment, and social risk factors: Determinants of the child welfare to juvenile justice transition among maltreated children and adolescents," Child Abuse Negl, pp. 7-18, 2017.

[14] Y. Xu, H. Ahn dan C. L. Bright, "Family involvement meetings: Engagement, facilitation, and child and family goals," Children and Youth Services Review, vol. 79, pp. 37-43, 2017.

[15] M. T. Schulle, L. Armistead, W. D. Marelich, D. L. Payne, N. M. Goodrum dan D. A. Murphy, "Maternal parenting strees and child perception of family functioning among families affected by HIV," Journal of the Association of Nurses in AIDS Care, vol. 28 , no. 5, pp. 784-794, 2017.

[16] C. H. Soetjiningsih, Karakter Enterpreuner dan Pola Asuh Orangtua, Solo: Universitas Muhammadiyah Surakarta, 2013.

[17] C. Peterson dan M. E. P. Seligman, "Character strenghts and virtues: A handbook and classification," dalam A Handbook and Classification, American Psychology Association, Oxford University Press, 2004.

[18] E. Novalia, D. Murwani dan A. Indrawati, "Parenting Style in Entrepreneurship Building on Children," IOSR Journal of Business and Management (IOSR-JBM), vol. 18, no. 10, pp. 76-81, 2016.

[19] A. Field, Discovering Statistics Using SPSS, London: Sage Publications, 2009.

[20] J. Buri, "Parental Authority Questionnaire,” Journal of Personality Assessment, vol. 57, no. 1, pp. 110119, 1991.

[21] R. Barriroh, "Pengaruh kepribadian dan pola asuh orangtua terhadap keberhasilan karier wirausahawan," Sekolah Tinggi Ilmu Ekonomi, Yogyakarta, 2020.

[22] S. A. Firdaus, "Hubungan antara pola asuh otoriter dengan pengambilan keputusan karir pada siswa SMK Teuku Umar Semarang," Universitas Diponegoro, Semarang, 2018.

[23] S. A. Anisah, "Pola asuh orangtua dan implikasinya terhadap pembentukan karakter anak," Jurnal Pendidikan Universitas Garut, pp. 70 - 85, 2011.

[24] P. Dewi, D. Purwana dan A. Wibowo, "Hubungan pola asuh, kurikulum kewirausahaan dan intensi berwirausaha mahasiswa fakultas ekonomi universitas negeri jakarta," Jurnal pendidikan ekonomi dan bisnis, pp. 1-22, 2017.

[25] A. N. Hanum, "Pengaruh mata kuliah kewirausahaan terhadap minat mahasiswa menjadi wirausahawan," Jurnal Unimus, pp. 1 - 13, 2016. 